\title{
Beszámoló az egészség társadalmi meghatározóival és az egészségegyenlőtlenségekkel foglalkozó szakértői munkacsoport üléséről
}

\author{
Report on the meeting of Expert Group on Social Determinants and \\ Health Inequalities
}

\author{
Szerző: $\quad$ Csizmadia Péter $\bowtie$ \\ Nemzeti Egészségfejlesztési Intézet
}

Beküldve: 2017.02.07.

doi: 10.24365/ef.v58i1.136

Kulcsszavak: egészségegyenlőtlenség, épített környezet, migráció

Keywords: health inequality, built environment, migration

\begin{abstract}
Az Emberi Erőforrások Minisztériuma Egészségügyért Felelős Államtitkársága jelölése alapján a Nemzeti Egészségfejlesztési Intézet (NEFI) részt vesz az Európai Bizottság által múködtetett, az egészség társadalmi meghatározóival és az egészségegyenlőtlenségekkel foglalkozó szakértői munkacsoport (Expert Group on Social Determinants and Health Inequalities) munkájában. A munkacsoport, legutóbbi ülését 2017. január 10-11-én tartotta Luxembourgban.

A megbeszélés első napján több prezentáció tért ki a különösen sérülékeny társadalmi csoportok egészségére, illetve az ezzel kapcsolatos teendőkre. E témában elsősorban a hajléktalanok és a migráció egészséget érintő problémáit, illetve ezek megoldási lehetőségeit mutatták be. ${ }^{i, 1}$ A migráció kiélezheti az egészségegyenlőtlenségeket az érkezőkkel szembeni diszkrimináció, illetve az emberi jogok sérelme révén. Említésre került az EU által finanszírozott VulnerABLE pilot projekt, amely a szakterület jó gyakorlatait gyújtötte össze.i"
\end{abstract}

\begin{abstract}
A találkozó második napján elsősorban az egészségegyenlőtlenségek csökkentését célzó együttes fellépés (joint action) szakmai előkészítése folyt. Az Európai Bizottság a 3. Európai Egészségprogram keretében előreláthatólag 2017 márciusában írja ki a pályázatot az együttes fellépésre, amely vélhetően 2017 nyarán kezdődik.

A pályázat tervezetében az alábbi munkacsomagok szerepelnek: a közös kezdeményezés koordinációja, disszeminációja, a kezdeményezés értékelése, az egészségegyenlőtlenségek jelentőségének integrálása a nemzeti egészségpolitikába, az egészségegyenlőtlenségek monitorozása, az egészségmagatartást befolyásoló épített környezet, migráció és egészség, a veszélyeztetett csoportok ellátáshoz való hozzáférése.

A NEFI tevékenységéhez az egészségmagatartást befolyásoló épített környezet munkacsomag kapcsolódik a legszorosabban, amelynek átfogó céljai: hozzájárulni az egészséges lakókörnyezet megteremtéséhez és fenntarthatóságához nemzeti, regio-
\end{abstract}

\footnotetext{
¡ Vándorlás vagy migráció alatt a népesség ideiglenes vagy tartós helyváltoztatását értjük, amelyet számtalan kiváltó ok (letelepedés, munkavállalás, tanulás, kikapcsolódás stb.) motiválhat. A szakirodalomban a migráció kifejezést általában azokra a népességmozgási folyamatokra használják, ahol a vándorlásban részt vevők helyváltoztatásuk során közigazgatási határt is átlépnek, tehát adott településen belüli mozgásokat ez esetben nem tekintik migrációnak. Pirisi Gábor, Trócsányi András Általános társadalom- és gazdaságföldrajz http://tamop412a.ttk.pte.hu/files/foldrajz2/(Elérve: 2017.02.07.) ii http://www.health-inequalities.eu/projects/vulnerable-groups/ (Elérve: 2017. 02. 14.)
} 
nális és közösségi szinten, csökkenteni az egészségegyenlőtlenségeket és támogatni az egészségfejlesztést. A specifikus cél stratégiák, szakpolitikák keresése, amelyek alapjául szolgálhatnak bizonyítékon alapuló jó, illetve ígéretesnek túnő gyakorlatoknak, az egészséges lakókörnyezettel kapcsolatban. Ezentúl érdemes létrehozni egy gyújteményt, amely támogató útmutatást adhat a döntéshozóknak és az érdekhordozóknak a témába. A munkacsomag a lakókörnyezet egészséges életmódra gyakorolt pozitív hatásainak a jobb megértését célozza, többek között ígéretes gyakorlatok azonosítása, a tagországok közötti tapasztalatcsere révén. A végső cél szakpolitikai ajánlások létrehozása, amelyek az egészséges lakókörnyezet kialakítását támogatják.

A megbeszélésen bemutatásra és megvitatásra került egy sablon is, amely segítségével átfogó kép készülhet a tagországok egészségegyenlőtlenségekkel összefüggő szakpolitikáiról, illetve a tagországok beszámolhatnak a szakterületen történt legfrissebb fejleményekről. Új kihívások jelentkeztek, amelyek nehezíthetik az egészségegyenlőtlenségek további kezelését. Európának a migráció további hullámaira kell felkészülnie, valamint a gazdasági válság, a megszorítások komolyan befolyásolják az európai polgárok életét, különösen a hátrányos helyzetúekét.

A tervezett együttes fellépés egy fontos lehetőséget testesít meg, hogy „Az egészség terén mutatkozó egyenlőtlenségek csökkentése az Európai Unióban” című közlemény ajánlásai a gyakorlatban is megvalósuljanak hatékony akciók formájában. ${ }^{2}$ Az Európai Bizottság és a tagországok közösen cselekednek majd, kiemelve az egészség társadalmi meghatározóinak szerepét és a tudatosság fokozását, figyelembe véve, hogy az akciók elmaradása károsan befolyásolja az egészséget, a társadalmi kohéziót és a gazdasági fejlődést.

Az együttes fellépést érintő eseményekről a későbbiekben is beszámolunk az Egészségfejlesztés folyóiratban.

\footnotetext{
${ }^{1}$ http://tamop412a.ttk.pte.hu/files/foldrajz2/(Elérve: 2017.02.07.)

2 http://ec.europa.eu/social/BlobServlet?docld=6265\&langld=hu (Elérve: 2017.02 .07 .)
} 